\title{
PERCEPTIONS OF THE PROBLEMS OF THE JEWISH POPULATION IN ODESSA JOURNALISM IN THE 50-60 OF 19TH CENTURY
}

\section{Olga Likhachova}

\section{INTRODUCTION}

The preparation of the socio-economic and political reforms of the second half of the 19 th century, which took place in the Russian Empire, led to significant changes in journalism and publishing. During this period, the government pursued a dual policy towards the press. On the one hand, when discussing transformation projects, they were interested in new ideas and approaches to solving problems that the press could provide. On the other hand, the authorities feared widespread discussion of state reform. In the late $1950 \mathrm{~s}$ and early $1960 \mathrm{~s}$, the issue of giving equal rights to Jews was urgently raised in journalism. This was triggered by a series of measures outlined by the government- on the one hand, and the emergence of literary public printing bodies- on the other. During this period Odessa became one of the most important cities in which the Jewish Enlightenment movement - the Haskalah - developed. Thus, the analysis of this regional press provides opportunities to consider a number of questions, both about the progress of reforms in the country and about the history of the formation of the liberal press and journalism in Odessa. The article presents an analysis of the positions of the periodicals of the "Odesskiy vestnik" and the "Rassvet" magazine on these issues. The Odessa Vestnik was founded in 1827 and was subject to the jurisdiction of the Office of the Governor-General. Until the mid 50 's of the XIX century. The "Odesskiy vestnik" was considered one of the oldest, most respected official press agencies in the Russian Empire. However, in its content, this newspaper was a little different from other publications that reported local news. It contained decrees reprinted from St. Petersburg newspapers, as well as official orders from local authorities. But after coming in 1856 to the post of the head 
of the Odessa educational district M. I. Pirogov, "Odesskiy vestnik" was transferred to the leadership of the Richelieu Lyceum. Despite the difficult censorship restrictions, the editorial staff of "Odesskiy vestnik" managed to change qualitatively the subject matter and ideological orientation of this newspaper. The "Odesskiy vestnik" has acquired a bright liberal orientation. The liberal-democratic orientation of the newspaper was most clearly reflected in the coverage of the problems of the Jewish population. The pages of Rassvet, the first Russian-language Jewish magazine, have been able to formulate a comprehensive program of necessary transformations to address the issue of emancipation of Jews in the Russian Empire. As an example of a vivid examination of the problems of Jews by Odessa publicists, the historical and journalistic "Essay on the Contemporary History of Judaism" by O.I. Georgievsky is analyzed. Consideration of issues of perception and reflection in the Odessa press and journalism of acute issues of reform of Jewish communities will give an opportunity to make a general picture of the vision of the further liberal development of Jewish society by the Odessa liberal press during this period.

\section{Formation of Views on the Problems of Reforming Jewish Communities in Odessa Journalism in 50-60 of 19th Century}

The question of the emancipation of the Jewish population arose in the late 1950s sharply. It is known that since March 1856 "Committee for Determining Measures of Indigenous Conversion of Jews in Russia" under the leadership of Count P. D. Kiselev resumed its work. With the direct involvement of P. D. Kiselev, the Committee has taken a course to improve the legal status of Jews, however, taking into account property or educational qualifications. The Committee proposed to gather the views of the Governors-General on the Jewish issue. Particular attention was paid to the position of the Novorossiysk and Bessarabian governor-general - the Count O. G. Stroganov, who advocated the equalization of Jews in their rights with Christians.

This proposal was supported by Minister of the Interior S. S. Lansky. However, this approach was rejected by the Committee. An important role was played by the position of a new head, Count D. M. Bludov, who advocated gradual steps in addressing this issue. However, on March 16, 
1859, a decree was issued granting the right of universal residence to Jewish merchants of the 1st Guild. The Committee has widely discussed the possibility of resettlement and other categories of the Jewish population ${ }^{1}$. Thus, even those brief testimonies pointed to the fact that during this period, it was in the south of the Russian Empire that a special social atmosphere was created, which contributed to the emergence of progressive views on the problems of the Jewish population. Let us turn to the analysis of the factors that led to such a course of events. It should be noted that it was Odessa, its public figures, journalists, and publicists who made a significant contribution to the discussion of these issues. In 1856 M. I. Pirogov was appointed as the head of the Odessa educational district. He initiated the transition of the "Odesskiy vestnik", a newspaper that was founded in 1827 and was subject to the jurisdiction of the Office of the Governor-General under the leadership of the Richelieu Lyceum. His idea was that the newspaper, under the editorship of the professors of this institution, would be a powerful source of education for the whole province. O. G. Stroganov, who held the position of Governor-General during this period, at first supported this idea. According to the decision of the Lyceum, young teachers O. M. Bogdanovsky and O. I. Georgievsky were appointed as editors of the "Odesskiy vestnik". Under the new edition, the newspaper began to be published on January 4, 1858. Three issues of the newspaper were published weekly. It should be emphasized that since this period the newspaper has completely changed the range of considered issues. One of the main issues discussed periodically on the pages of this publication was the issue of the Jewish population. M. I. Pirogov was one of the first to address these problems. His article was published in the spring of 1858 under the title "Odessa Talmud-

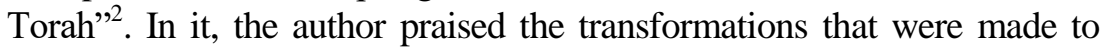
charity at an educational institution where orphans and low-income families were educated. The trustee of the educational district considered the experience of the "Odessa Talmud-Torah" extremely important not only for Jewish educational institutions but also triggered extending the

${ }^{1}$ Mindlin, A. B. (2005) Imperator Aleksandr II i “evreyskiy vopros" [Emperor Alexander II and the Jewish Question]. Paralleli - Parallels, 6, 23-26 [in Russian]

${ }^{2}$ Pirogov M. I. (1858) Odesskaya Talmud-Tora [Odessa Talmud-Torah].

Odeskiy vestnik - Odessa Herald, 26, 1-2 [in Russian] 
example of charity raising to other schools. All the ideas of M. I. Pirogov were fully understood and supported in the edition of the "Odesskiy vestnik". The editorial board of the "Odesskiy vestnik" encouraged discussions of prominent Jewish figures on the pages of the newspaper. Many Jewish authors began to publish their articles in the newspaper: J. Rabinovich, I. Tarnopol, and others. For the first time, a Jewish issue was covered so widely on the pages of a Russian-language newspaper. In 1858 , more than ten articles were devoted to this problem. Gradually, on the pages of the "Odesskiy vestnik", the personal attitude of the editorial staff in solving the main problems of the Jewish population was born. The "Odesskiy vestnik" has repeatedly emphasized the need for rapprochement between Jews and other nations, it was only possible as a result of success in the education system on both sides. The editorial position on the Jewish theme has caused serious resonance not only in the local but also in the capital's press. Governor-General O. G. Stroganov was also dissatisfied with the activities of the trustee of the educational district M. I. Pirogov, and the edition of the "Odesskiy vestnik". In February 1858, he wrote to the Minister of Public Education that the positions of the new edition of the newspaper lead to the development of the harmful direction. A. Egorov (Konsparov), a memoirist, who held various positions in the censorship organizations of the Russian Empire for many years, wrote in his illustrated documentary about the difficult situation surrounding the "Odesskiy vestnik" ${ }^{3}$. Even though the newspaper was published on favorable terms for the city treasury, namely, refused the proceeds of the publication in favor of the printing press and paid the Lyceum 1500 rubles annually, the local government decided to get rid of it $^{4}$. The reason was found in numerous remarks of the General Directorate of Censorship in St. Petersburg. It repeatedly condemned and reprimanded the local Odessa censors for publications of the "Odesskiy vestnik". In this regard, it was decided to re-transfer the "Odesskiy vestnik"to the

3 Egorov, A. (Konsparov) (1913) Stranitsy iz prozhitogo [Pages from lived]. Odessa: "Slavyanskaya" tipografiya E. Khrisogelos [in Russian]

${ }^{4}$ Grebtsova, I. S. (2002) Periodicheskaya pechat' v obshchestvennom razvitii

Yuzhnogo stepnogo regiona Rossiyskoy imperii (vtoraya tret' XIX v.) [Periodic press in the social development of the Southern steppe region of the Russian Empire (second third of the 19th century]. Odessa: Astroprint [in Russian] 
Governor-General. In the last issue of the newspaper, the editorial board summarized its activities, stating: “... We worked hard and didn't work for nothing: we proved... that in the provinces, not in some capitals, true literary and journalistic activity is possible..." 5 . It should be noted that the new collection was dedicated to M. I. Pirogov, who by this point had already been transferred to the post of trustee of the Kyiv Educational District. A new collection has also found a place in Jewish journalism. On its pages, an article by J. Rabinovich "On the Names of Jews " was published, which is considered one of the first examples of Jewish scientific and journalistic activity on the pages of the Russian-language edition. Note that the new collection was dedicated to M. I. Pirogov, who by this point had already been transferred to the post of trustee of the Kyiv Educational District. And in many respects, this new appointment was linked to his liberal views on the problems of the emancipation of the Jewish population. But after M. I. Pirogov left Odessa, he did not neglect the problem of Jewish periodicals. He endorsed the main goals of the new edition: the education and equality of Jews in the Russian Empire. The journal was supposed to publish materials on the life of Jews, their historical past, as well as articles on current issues. In his letter to the publishers of a new magazine published in one of his issues, M. I. Pirogov noted: "Whatever side we look at for Jewish people, there is no rational reason why we would not want what we want to ourselves: respect for the beliefs of conscience, for the individual, for the merits of everyone, there is no reason why we would not want the Jews to benefit from our common homeland and enjoy its benefits for that reason... without passion for everything truly human, they must open their new regular ranks for all burdened with the struggle for universal enlightenment... I do not need to explain to what extent I sympathize your publication. God forbid that it may spread a view similar to the one I have outlined ${ }^{6}$. And it is even more desirable than the "Rassvet", with the assistance of the thoughts and beliefs, would serve to unite and interact with all educated Jews. Thus, the new foundations of the magazine "Rassvet" were laid, which began to be

5 Bogdanovskiy, A., \& Georgievskiy, A. (ed.) (1858) Peredovaya stat'ya [Editorial]. Odesskiy vestnik - Odessa Herald, 119, 1 [in Russian]

${ }^{6}$ Bogdanovskiy, A., \& Georgievskiy, A. (ed.) (1859) Novorossiyskiy literaturnyy sbornik [Novorossiysk literary collection]. Odessa: P. Frantsova. [in Russian] 
published in Odessa on May 27, 1860. This magazine became the first Jewish periodical to be published in the Russian Empire. Its publishers were J. Rabinovich and I. Tarnopol. A whole galaxy of talented publicists and scholars has been involved in publishing. Within the magazine, the authors such as I. Yost and S. Pinsker and ordinary representatives of the Jewish community of the city were able to print their works. O. I. Georgievsky became one of the active participants of the editorial board and presenter of a regular column of the magazine under the name "Review of Foreign Jewish Journalism".

The editorial board viewed him as a talented journalist and publicist. Moreover, his role in the publication of the magazine was recognized as brilliant even by people who were dissatisfied with the actions of the editorial staff. Thus, one of the issues of the magazine contained a letter from an angry author who did not find his material in the published issue and was convinced that he was not allowed by O. I. Georgievsky. Nevertheless, he wrote: “ O. I. Georgievsky has a brilliant talent, it is not surprising that such a figure can be seen as a worthy employee of the editorial board of the magazine"7. It should be noted that this episode shows that the duties performed by O. I. Georgievsky were not limited to journalism, but also related to editing of the magazine. The magazine began to highlight major changes in the lives of Jews, based on an analysis of the most important European publications. The point was that the first issue had to be revised by censorship. Therefore, it was not possible to raise acute problems for the Jewish community. But the editorial board found a solution and talked about all the problems through the lens of Western European Jewry. At "Rassvet" there were translations of authors from German, French, Italian, English. About the benefit of this approach, the editorial wrote: "In literature in general, and in journalism specifically reflects the whole life of any people with its temporal and eternal, material and moral interests, pleasures and sorrow" ${ }^{\prime \prime}$. There was no doubt about the influence of journalism on the

\footnotetext{
7 Rabinovich, Y. (ed.) (1860) Pis'mo v redaktsiyu "Rassveta" [Letter to the editors of "Rassvet"]. Rassvet - Sunrise, 27, 432 [in Russian]

${ }^{8}$ Georgievskiy, A. (1860) Obzor inostrannoy evreyskoy zhurnalistiki [Review of Foreign Jewish Journalism] Rassvet - Sunrise, 1, 9-13 [in Russian]
} 
socio-political and spiritual component of society. Thus, "Rassvet" called for addressing the internal problems of Jewish society by examining similar problems of the Jewish world outside Russia. At the same time, the magazine insisted on the need not only to deal solely with the Jewish issue in the humanitarian sphere but also to pay attention to their contribution to the development of all European states through the diverse socio-economic activities of the Jews. Before that, according to the editorial board, there was every reason. "By their real and moral capital, Jews undoubtedly bring great benefit to the country that serves them as a native...", the journal noted ${ }^{9}$. In the developed countries of Western Europe, this process of disappearance of prejudice and hidden persecution against the Jewish community was gaining momentum during this period. Undoubtedly, this process was greatly facilitated by the active participation of Jews in the sociopolitical life of the countries in which they resided. Thus, one can distinguish the problem of the influence of the socio-political activity of the Jewish population on the development of the leading European countries as one of the most important problems addressed in several articles of the "Rassvet". Indeed, the magazine provided examples from the recent history of Western European countries that showed close co-operation with other nations, especially in the course of hostilities. The magazine wrote about the service of the Jews in the French National Guard. His articles contained examples from the lives of hundreds of Jews who joined D. Garibaldi's national liberation movement in Italy. Much attention was paid to the equation in the rights of the Jewish population of Lombardy, Parma, Modena, and Tuscany with other subjects after unification with Piedmont. According to the magazine, this process was a direct consequence of the fact that the Jews of these territories saw their future in the united national Italian state and fully contributed to its creation. Serious attention was paid to the issue of uniting Jews in European countries to protect their rights. Several articles were devoted to the various forms and methods of this activity. Thus, concerning the letter addressed to

\footnotetext{
${ }^{9}$ Georgievskiy, A. (1860) Obzor inostrannoy evreyskoy zhurnalistiki [Review of Foreign Jewish Journalism] Rassvet - Sunrise, 4, 55-57 [in Russian]
} 
the Jews of all countries by the Italian Jews who were oppressed by the Roman Curia, it was written in the journal: "We do not know yet whether this voice will despair the hearing of the Rothschilds, Pereira, Miressi, Goldemides, Montefiore, and others, the fact that we have presented is remarkable... because the idea of appealing to the oppression of Roman curia by fellow believers in all European countries is a product of modern times"10. Opposed to one of the important struggles of the Jewish people, "Rassvet" considered the idea of the creation of public-Jewish organizations. During this period, similar projects were discussed on the pages of the Common Judaism Newspaper, which outlined the idea of widespread governmental involvement in the creation of such organizations. With such a course of events, the edition of "Rassvet" could not stay positive about. According to the magazine, the initiative must have been raised by Jewish society and unite Jews in solving the most acute and serious problems. The magazine cited several high-profile cases that caught the attention of not only the Jewish population but also became known throughout Europe. These include the abduction of a Jewish child by Catholic priests in Bologna to raise her in the Christian faith, the escape of several thousand Jews from Morocco, the situation of Jews in the Danube principalities. Such difficult life situations, according to the editorial staff, helped to realize the unity between the Jews of all countries. The magazine argued that such unity would lead to the disappearance of national-religious differences if it were only about human interests and inalienable human rights. "More often the Jews, despite their displacement around the world, will have the opportunity to act at the same time and in their affairs, which arouse compassion among Christians. More they will be concerned with the consciousness of their unity and more they will come closer to Christians", was written in the journal ${ }^{11}$. The magazine paid particular attention to the situation in Gibraltar following the fleeing of four thousand Jews who were persecuted in Morocco. After a detailed examination of the

${ }^{10}$ Georgievskiy, A. (1860) Obzor inostrannoy evreyskoy zhurnalistiki [Review of Foreign Jewish Journalism] Rassvet - Sunrise, 5, 76-77 [in Russian]

${ }^{11}$ Georgievskiy, A. (1860) Obzor inostrannoy evreyskoy zhurnalistiki [Review of Foreign Jewish Journalism] Rassvet - Sunrise, 10, 156-159 [in Russian] 
history of this situation, the magazine with optimism emphasized: "But now the wounds inflicted by fanaticism and barbarism, if possible, have been immediately treated by education and philanthropy, without distinguishing between nationalities and religions" ${ }^{12}$.Fundraising has begun across Europe to support this mass of disadvantaged people. And the money was donated by Catholics, Protestants, and Jews. Based on the analysis of articles on the problems of the unification of Jews living in different states of Europe, we can trace the process of transforming the idea of editing a magazine about the benefits of charitable actions within Jewish communities to the idea of charity for the benefit of representatives of any nationality subject to national or religious oppression. As an example, one of the featured material about fanatical attacks on Christians in Syria. In this regard, the magazine highlighted the explicit approval of the proposals of the former member of the provisional government of France, a Jew by nationality, A. Premier to create a standing committee to oversee all encroachments on the freedom of conscience, and cash assistance to all victims of fanaticism. It should be emphasized that the problems of establishing charitable foundations and commissions, the need for Jews to be aware of their unity, especially in the face of the ongoing national conflicts, were of interest to the magazine and not about satisfying the curiosity of readers. The magazine addressed a serious and profound problem. According to the magazine, the high-profile cases, which excited the majority of Europeans without differences of nationality and religion, showed complete indifference to the Jews who lived in Russia. The editors noted: "We do not know of any pan-European cause in which Russian and Polish Jews are involved with the masses... All these disasters reach the hearing, but not to the hearts of Russian and Polish Jews: at least, they remain inactive" ${ }^{\text {"13 }}$. Editors suggested that such behavior may be due to fears of showing themselves more to Jews than to nationals. But this attitude, according to the magazine, namely the inaction in helping Syrian Christians cannot be justified.

${ }^{12}$ Rabinovich, Y. (ed.) (1860) Peredovaya stat'ya [Editorial] Rassvet - Sunrise, 21, 338 [in Russian]

${ }^{13}$ Georgievskiy, A. (1860) Obzor inostrannoy evreyskoy zhurnalistiki [Review of Foreign Jewish Journalism] Rassvet - Sunrise, 10, 156 [in Russian] 
The magazine expressed the optimistic opinion that the magazine's editorial board would increasingly be able to talk about the charity of both Jews and Christians in favor of Jews. Already in the next issue of the magazine was announced the start of fundraising for the benefit of Syrian Christians. In total collected 285 rubles of silver, of which 10 rubles were donated by the editorial board of "Rassvet". In the next group of articles, "Rassvet" addressed the problem of conservatism in the Jewish communities. It developed the view that many of the problems of the Jews were rooted in the orthodoxy of Jewish society, alert to any, even minor, changes. These traits, according to the editors of the magazine, often hindered progress. The magazine often used the example of Germany to confirm this position. According to "Rassvet", even though the process of reform of Judaism in this country was much faster than in other countries, but every step forward, every innovation met with strong resistance from the jealousy of antiquity. The need for change in Jewish society is also reflected in several publications on Moldovan Jews. Discussing in the articles the possible ways of the progressive development of the Jewish community, the editorial office of "Rassvet" directly linked this path with the new trends in education. Thus, there is another important issue that has been covered in journal articles. This was the problem of providing the Jewish population with modern education opportunities. The editorial staff was convinced that enlightenment is the key to the spiritual, moral and material well-being of present and future generations. The magazine directly stated this: "Schools that meet the multilateral needs of time are the true basis and the most reliable source of people's well-being" ". On the pages of "Rassvet" was presented a complete picture of the status of Jewish education in developed countries of Western Europe, its pros and cons were evaluated. Considering the situation in Austria and Galicia, the magazine noted that there is still a widespread education there with the help of melamed and heads. Not only this is bad for general education, but it leads to the decline of religious education, to the spread of Hasidism. About governmental measures, some considered the

\footnotetext{
${ }^{14}$ Rabinovich, Y. (ed.) (1860) Peredovaya stat'ya [Editorial] Rassvet - Sunrise, 21, 338 [in Russian]
} 
magazine ambiguous. For example, Jews were granted land titles only after they had completed their coursework. In this case, the magazine's editorial staff, fully aware of the government's objectives and supporting them, nevertheless disagreed with the coercive system. The magazine noted that Jews rarely concede to violent measures, they only cause violence in their environment.

As a result of a thorough discussion of the state of development of the Jewish communities, the journal identified the countries where the greatest progress was made in the education and emancipation of the Jews. Thus, the magazine has set the benchmarks that Jewish communities and the state should seek. According to the magazine, full religious freedom only met in the North American United States, where any religion hadn't had the right for assistance from the state. Also, to a smaller extent, in France, where, according to the magazine, the government patronized and assisted all religions. The magazine described a vivid episode about it. Namely, Napoleon III's gift to the Parisian Jewish community of the Torah scroll, solemnly introduced by the emperor himself in the main synagogue of Paris ${ }^{15}$. The analysis of European materials allowed the magazine to focus on the study of the education of Jews in Russia. The editorial staff noted, that we are convinced that there will be many capable and deserving administrators, judges, especially professors and teachers among Russian Jews, and when all these position become available to them, they will undoubtedly bring significant benefits to all branches of the civil service. Almost all magazine articles on Jewish education in Russia indicated a positive example of Jewish joint education with representatives of other nations and religions. The opportunity to receive a full-fledged modern education was considered by the magazine to be one of the foremost tasks for Jews living in the country. It should be noted that the views of the Dawn editorial board on changes in traditional Jewish education did not always coincide with those of orthodox Jewish leaders. They feared that any changes in this

\footnotetext{
${ }^{15}$ Rabinovich, Y. (ed.) (1860) Peredovaya stat'ya [Editorial] Rassvet - Sunrise, 46, 739 [in Russian]
} 
area would entail changes in the norms of Judaism and would adversely affect the national identity of the Jewish people ${ }^{16}$. However, studying the issue of Jewish education in Russia allowed the magazine's editorials to touch on another pressing topic. The magazine has repeatedly noted the negative impact of the artificial restriction on the residence of Jews throughout the Russian Empire on the habitation strip. The editors of the magazine were irreconcilable critics of the residency band, but because of censorship restrictions, they could address this topic only based on the experience of Western European countries. However, the attentive reader could easily see in the calls for the modernization of Jewish education, the possibility of obtaining a full-fledged, up-to-date education, above all, a call for the elimination of the lane. It should be noted that the dawn articles on the fastest possible solution to the problem of emancipation of the Jews, as well as the general liberal orientation of the editorial board, caused dissatisfaction with the local and central censorship bodies. This led to the closure of the magazine, the last issue of which was published May 19, 1861.

Thus, the pages of the "Odesskiy vestnik" and the magazine "Rassvet" reflected the current problems of the development of Jewish communities. Considerable attention was paid to the need for developing charity, which in turn would facilitate the development of public relations between Jews and Jewish communities, as well as the development of international relations. The complex of problems connected with obtaining modern secular education was considered. This issue made it possible to move on to the most significant problem - the elimination of the lane. In general, Odessa journalists managed to formulate a comprehensive program of necessary changes to address the issue of giving political and civil rights to Jews.

\footnotetext{
${ }^{16}$ Tsinberg, S. L. ( 1915) Istoriya evreyskoy pechati v Rossii v svyazi s obshchestvennymi techeniyami [The history of the Jewish press in Russia in connection with social movements] Petrograd: I. Fleytmana [in Russian]
} 


\section{2. "An Essay on the Contemporary History of Judaism"} as a Model of Liberal Publicistic Perspective on Reform Problems

An important topic for the editorial board of "Rassvet" was the topic of reform that was evidenced by the fact that these issues were considered by one of the editors of the journal O. I. Georgievsky in a separate historical study called "Essay on the Contemporary History of Judaism". This work was published in March 1860 in the radicaldemocratic journal "Russkoe slovo"17. But a broad response has elicited this study from the southern Jewish population. "Rassvet" provided opportunities to discuss the work on its pages. So, let's turn to the basic foundations of this historical and journalistic work. At the beginning of this fundamental work, the author drew the readers' attention to the peculiarities of the modern historical period. In his opinion, modernity required solving new issues and tasks that arose with unprecedented speed in various spheres of state, public, and religious life. All these changes, in his opinion, were especially relevant and necessary for the Jewish people. He reminded that Jews make up a large part of the population of the Russian Empire, which means that their fate is closely related to the interests of other citizens of the state. It should be noted that the work itself was dedicated to the author, the writer, the founder of Jewish literature in Russian, and the editor of the first Jewish magazine published in Russian Y. A. Rabinovich. In connection with the new tendencies that arose in the solution of the Jewish question in the late $1950 \mathrm{~s}$. O. I. Georgievsky insisted on the need for close attention to the sociopolitical problems of the Jews, both from the state and from the public. In his essay, he carefully analyzed the work of the famous Judaist theorist S. Stern, which was published several years earlier in Germany. In his essay, O. I. Georgievsky not only introduced readers to its content but also expressed his views on reforms. He considered and analyzed the main views contained in this historical essay. Research can be divided into three main parts. In the first part, the author analyzed the historical roots of Judaism. The second part

\footnotetext{
${ }^{17}$ Georgievskiy, A. (1860) Ocherk sovremennoy istorii yudaizma [Essay on the Contemporary History of Judaism] Russkoe slovo - Russian word, 3, 1-58 [in Russian]
} 
deals with the main tendencies of reforming Judaism in Western Europe. And finally, the third part of the study contained an analysis of new trends in the development of Jewish communities in Russia and the necessary changes, according to the author. Considering the historical role of Judaism, O. I. Georgievsky noted that he is grateful for this collection of moral and ethical norms that the Jewish people, despite their very difficult historical periods, managed to preserve in their identity. He began to study the historical roots of Judaism since the Middle Ages. This period he considered the most difficult for the Jews. The author emphasized the great historical significance of Judaism during this difficult period. "The Talmud in these centuries of sorrow was their moral auspices, the stronghold of their national and religious identity, and without it, they would perish among the flood of hatred common to them", he wrote ${ }^{18}$. At the same time, O. I. Georgievsky noted that it was this isolation that virtually shielded the Jewish people from socio-historical progress. By the end of the Middle Ages, under the influence of evolving science and literature, the countries of Western Europe had made a major step forward on the road to tolerance. In countries where Protestantism began to assert itself with the onset of modern times, the Jewish population grew steadily. In the XYII century. Spanish or so-called Portuguese Jews were actively migrating to souther France, to western Germany and, in particular, to the Netherlands. The author noted that these migrants were rich and had an excellent education, which differed significantly from their fellow peers. Because of them, Europe was scattered about Jews as orthodox and ignorant. Thus, the author of the essay understood the centuries-old, strict adherence to the norms of Judaism, due to rigid historical causes. This way allowed the Jews to maintain their national identity. Nevertheless, the author was analyzing the history of the Jewish people in modern times, concluded the possibility and necessity of reforms. The examples in his study were to re-emphasize the reformist potential contained in Judaism. He was convinced that many of the norms of Judaism were obsolete so that

${ }^{18}$ Georgievskiy, A. (1860) Ocherk sovremennoy istorii yudaizma [Essay on the Contemporary History of Judaism] Russkoe slovo - Russian word, 3, 3 [in Russian] 
they could not be governed in the present day. At the same time, the reform process can be directed in such a way that the Jewish law will be preserved, but it will make such changes necessary for the Jewish society that would contribute to historical progress. In the second part of his work, O. I. Georgievsky, while analyzing the historical stages and progress of reforms to resolve the Jewish issue in Western Europe, focused on the specific problems facing the Jewish communities in Russia. This approach, according to the author, would avoid many mistakes by the state during the period of transformation. First of all, he referred to the example of Prussia. In 1750, a "general Jewish privilege" was promulgated in Prussia, which, according to the author, contained many more humiliating provisions. However, because of this document, Jews were able to view Prussia as their homeland and not as a temporary residence place. He wrote, that The successes of European education and philanthropy marked the beginning of the return of Jews to common life and, over time, brought them out of the suffocating sphere of medieval Judaism into the wide field of universal education.

In the historical study, both the positive and the negative aspects of the traditions of Jewish education were considered. Positive phenomena were attributed to the fact that in the eyes of every Jew, even the common man there is no religion without science and there is no teaching without religion. On the other hand, it was noted that in the case of adherents of orthodox Judaism, all doctrines are reduced only to mastering the abstract legal and religious definitions of the Talmud. The author asserted: "Not one, perhaps, a thousand mental gifts have perished among the merciless, premature mental torture, carried out even now and thereby seven tireless and uneducated melamed"19. Thus, the author emphasized that the reform of Judaism should begin with the reform in the field of Jewish education. Studying the reforms in Austria, the author emphasized the fact that the process of emancipation of the Jews in this country was initiated by the government, which could explain the strong resistance to these reforms among the Austrian Jews. This historical fact served as the author's

${ }^{19}$ Georgievskiy, A. (1860) Ocherk sovremennoy istorii yudaizma [Essay on the Contemporary History of Judaism] Russkoe slovo - Russian word, 3, 15 [in Russian] 
further confirmation of the theory that has repeatedly appeared on the pages of "Rassvet". Namely, the decisive role in the cause of any transformation was played by a deep interest in their implementation by the people. A serious argument in favor of this was the example of the history of solving the Jewish question in France. It should be noted that the decree of October 14, 1789, gave French Jews equal rights with Christians. However, according to the author, neither Christians nor Jews in their mass were ready for that: some accepted Jews into their midst, others became full-fledged citizens in Christian society. In this regard, local authorities had to take the most vigorous measures to save Jews from persecution. At the same time, the author focused on several serious positive changes that have occurred recently in the environment of French Jews. "All the Jews of France have mastered the French language, willingly approaching the whole population, not differing in any external features, occupying the highest and highest positions and positions in the state and society," he wrote ${ }^{20}$. Analyzing the historical views of O. I. Georgievsky on the Jewish issue, which he formulated in the Essay on the Contemporary History of Judaism we can state the fact that the author preferred the progressive movement on the part of the state as a response to the changes already made within the Jewish community. This conviction is particularly striking in the third part of his work on the problems of Jews living in the Russian Empire. He acknowledged that for Jews living in Russia, only the dawn of the new age was coming. However, he was convinced that the changes that had taken place in the daily lives of Jewish communities were becoming increasingly apparent. For example, from Western Europe, reformed and updated Jewish schools gradually moved to east. As proof of this, it was presented with facts from the life of the Odessa Jewish community. First of all, he mentioned the activities of Bezalel Stern, through the efforts of whom a Jewish school was opened, which focused not only on the study of the Talmud but also helped the students to acquire secular knowledge, in particular, to

${ }^{20}$ Georgievskiy, A. (1860) Ocherk sovremennoy istorii yudaizma [Essay on the Contemporary History of Judaism] Russkoe slovo - Russian word, 3, 18 [in Russian] 
learn Russian and German. As a result, European education has increasingly penetrated the Jewish environment.

However, O. I. Georgievsky noted that the reform should not only copy the existing European experience but also take into account local conditions. He advocated the idea of compatible learning. In this way, it would be possible to attract not only young people of Jewish nationality to the renovated schools but also to involve children of Christian faith. In these schools, they could study common subjects together. Such examples have already been known in Europe. Also, such a system would allow representatives of different denominations to get to know each other better, giving them even greater chances of coming together and overcoming prejudices. The author praised the examples of Jewish participation in literary activities in Russian. Therefore, the author warmly welcomed the literary work of J. Rabinovich. At the same time, he emphasized that such activities are in no way related to apostasy he supported as author of the essay and the desire of Jewish youth to gain knowledge in high schools and universities. To prove this, the essay contained several important statistics that characterized the situation in the field of Jewish education. Analyzing this data, the author noted that the successes of Jewish education were beyond doubt. He was convinced that universal education would find much more common ground for Christians and Jews, and thus help to eliminate the existing contradictions. Particular attention was paid to Jewish charity work. In this regard, he praised the charity of the Jewish community in Odessa, thanks to which the Talmud-Torah was donated. Also, the Jewish community of Odessa invited Dr. S. Schwabacher, to the position of chief rabbi. He was associated with his work as an author of a favorable outlook for Judaism reform in the Jewish community in Odessa. An important milestone in the dissemination of scientific knowledge and education in the Jewish environment of Russia, O. I. Georgievsky considered the publication of the magazine in Russian. On the one hand, he would acquaint the Russian public and the Russian government with all the peculiarities of the way of life, character, aspirations, views, and interests of the Jews. Upon careful consideration of O. I. Georgievsky's essay, it becomes apparent that the author 
emphasized great importance not only to changes within the Jewish communities but also to a progressive movement for progress that was impossible without a thoughtful policy on the part of the state. In connection with this, the author sharply criticized the existence of a strip of residence in Russia. In his deep conviction, the ban on resettlement throughout Russia adversely affected not only the fate of the Jews but also contradicted the interests of the state. This prohibition, which artificially shielded Jewish communities from the rest of the world, contributed to their further orthodox development.

The author believed that permission to settle everywhere would lead to mass migrations. Only some Jewish families who have embraced European education would dare to do so. For the rest, it would be extremely difficult to take such a step. This would require knowledge of the language, traditions, and customs of your chosen place of residence. The example of Germany, according to the author, eloquently testified that progressive changes in Jewish communities were preceded by a permit for universal residence. A major role in the reform process, the Jewish society's readiness for the planned changes. Assessing the prospects of the emancipation of Jews in Russia, the author of the essay considered it was only a matter of time. "It would be strange in a modern state to alienate thousands and hundreds of thousands of subjects which, either in language, law, customs, crafts or education, do not differ from the rest of the population", he argued ${ }^{21}$. It should be noted that the views presented in the Essay on the Contemporary History of Judaism and the vision of the necessary transformations of Judaism were ambiguous in the Jewish community. It should be emphasized that O. I. Georgievsky's position reflected the sentiment of only a part of the reform-minded, advanced Jewish intelligentsia. It should be noted that both the "Rassvet" magazine and the "Essay on the Modern History of Judaism" found a significant reflection of the idea of Haskalah. This Enlightenment movement originated in the eighteenth century in Europe and was intended to modernize Jewish society. The Haskalay activists paid much attention

${ }^{21}$ Georgievskiy, A. (1860) Ocherk sovremennoy istorii yudaizma [Essay on the Contemporary History of Judaism] Russkoe slovo - Russian word, 3, 18 [in Russian] 
to the idea of providing modern secular education to the Jewish population. Opportunities for closer communication between Jews and other nations. Adoption and perception of common ideals of European culture by Jewish communities. It is no wonder, then, that the process has had its supporters and equally serious critics.

Thus, in the Essay on the Contemporary History of Judaism, the historical roots of Judaism were outlined. For centuries, on the one hand, they have helped to preserve Jewish identity in difficult political conditions, and on the other, in the author's view, have helped to preserve the conservative foundations of Jewish society. Thus, analyzing the reforms carried out in Western Europe aimed at modernizing the Jewish communities and giving equal rights to the Jews, the author outlined the concept of necessary transformations in the fields of education, charity, and social relations. At the same time, the Jewish community itself should have initiated the reforms. This factor would be a valid argument for achieving the overriding goal of abolishing the seatbelt and obtaining equal rights.

\section{CONCLUSIONS}

So, it should be emphasized that in the Odessa periodicals and journalism in the late 50 's - the early ' 60 s of the XIX century the problems associated with the emancipation of the Jews had significant importance. The Odessa Gazette was one of the first periodicals that addressed issues related to the life of the Odessa Jewish community. The pages of " Rassvet" magazine have already been able to formulate a comprehensive program of necessary changes to address the issue of giving political and civil rights to Jews. Much attention was paid to the unity of Jews, especially in the face of interfaith conflict. From the same point of view, the issue of mutual assistance of the Jews and the development of charity were considered. Particular attention was paid to political and social equality issues by journalism. Drawing on numerous examples of leading Western European countries, the publicists have emphasized the positive role that Jews have increasingly played in various areas of public service. Despite the numerous reforms aimed at modernizing the Jewish communities, which referred to the "Essays on the Contemporary History of 
Judaism," liberal journalism emphasized the need to preserve national identity, religious beliefs, urged to develop its culture, preserve its traditions. Thus, on the pages of the liberal Odessa newspapers, the works of publicists formed a solid foundation, which was intended to activate the social activity of the Jewish population. In the opinion of Odessa journalists, an active civic stance on the part of the Jewish communities would help speed up the process of giving Jews equal rights and freedoms.

\section{SUMMARY}

The article discusses the problems faced by Jewish communities in the middle of the 19th century and their reflection in the Odessa liberal press. The regional aspect of the issue has been selected concerning the following factors. First, the Committee on Determining Measures for the Indigenous Conversion of Jews in Russia came into force during this period. That is why the attention of the authorities was drawn to the south of the country because it was a place of residence of a large Jewish population group. Besides, Odessa became one of the leaders of Haskala. At this point, the establishment of national Jewish journalism began, and talented writers, journalists, and publicists merged their forces to reform all areas of the cultural and social life of Jewish communities. Considering the problems of the existence of the Jewish population in the Russian Empire, the activities of M. I. Pirogov cannot be ignored. While serving as the head of the Odessa educational district, he didn't only draw the attention to the periodical press which emphasized the problems of the Jews, but also personally contributed to the discussion of these problems. M. I. Pirogov made a significant contribution to the creation of the national Jewish press, which was published in Russian, he also defended the opening of the magazine "Rassvet" from some authorities. On the pages of this newspaper, during the hard conditions of censorship, journalists were still able to raise the issues of Jewish communities within the country. Issues of inter-confessional conflicts were also discussed in the journal. With the example of Western Europe and the United States, the magazine provided an analysis of state reforms aimed at promoting Jewish rights. This analysis provided 
an opportunity to move on with a discussion on the necessary reforms in the country. Planned step-by-step conversations, initiated by the Jewish society itself, would, in the opinion of the magazine's publishers, create a favorable atmosphere for governmental action aimed at emancipating Jews. The great attention that "Rassvett" has given to reform issues has pushed one of the editors of this edition, O. I. Georgievskiy to the writing of the socio-historical work "Essays on the Contemporary History of Judaism". Without prejudice to Judaism as a religious doctrine, he reasonably argued for the rejection of his most outdated norms. The author of "An Essay on the Contemporary History of Judaism" advocated the joint training of representatives of different denominations, which, in his opinion, would help to eliminate any national prejudices. Thus, the work raised the issue of the elimination of the sediment band, and thus one of the main restrictions on the disappearance of the national character. And, if the "Rassvet" was mainly highlighting the idea of the necessary increase of the social activity of Jews as a pledge of reforms, the "Essay on the Contemporary History of Judaism" considered the elimination of the habitation lane as the first step on the path of reform by the state authorities. Thus, liberal journalists from Odessa contributed fully to the improvement of the cultural and educational level of the Jewish population, upholding the idea of strengthening cultural and historical ties between people. They were deeply convinced that only fruitful cooperation with the state on the one hand, and preservation of national identity on the other, would make a serious step forward in the emancipation of Jews in all European countries.

\section{REFERENCES}

1. Mindlin, A.B. (2005) Imperator Aleksandr II i "evreyskiy vopros" [Emperor Alexander II and the Jewish Question]. Paralleli Parallels, 6, 20-38 [in Russian]

2. Pirogov M. I. (1858) Odesskaya Talmud-Tora [Odessa TalmudTorah]; Odeskiy vestnik - Odessa Herald, 26, 1-2 [in Russian] 
3. Egorov, A. (Konsparov) (1913) Stranitsy iz prozhitogo [Pages from lived]. Odessa: "Slavyanskaya" tipografiya E. Khrisogelos [in Russian]

4. Grebtsova, I. S. (2002) Periodicheskaya pechat' v obshchestvennom razvitii Yuzhnogo stepnogo regiona Rossiyskoy imperii (vtoraya tret' XIXv.) [Periodic press in the social development of the Southern steppe region of the Russian Empire (second third of the $19^{\text {th }}$ century]. Odessa: Astroprint [in Russian]

5. Bogdanovskiy, A., \& Georgievskiy, A. (ed.) (1858) Peredovaya stat'ya [Editorial]. Odesskiy vestnik - Odessa Herald, 119, 1 [in Russian]

6. Bogdanovskiy, A., \& Georgievskiy, A. (ed.) (1859) Novorossiyskiy literaturnyy sbornik [Novorossiysk literary collection]. Odessa: P. Frantsova. [in Russian]

7. Rabinovich, Y. (ed.) (1860) Pis'mo v redaktsiyu "Rassveta" [Letter to the editors of "Rassvet"]. Rassvet - Sunrise, 27, 432 [in Russian]

8. Georgievskiy, A. (1860) Obzor inostrannoy evreyskoy zhurnalistiki [Review of Foreign Jewish Journalism] Rassvet Sunrise, 1, 9-13 [in Russian]

9. Georgievskiy, A. (1860) Obzor inostrannoy evreyskoy zhurnalistiki [Review of Foreign Jewish Journalism] Rassvet Sunrise, 4, 55-57 [in Russian]

10.Georgievskiy, A. (1860) Obzor inostrannoy evreyskoy zhurnalistiki[Review of Foreign Jewish Journalism] Rassvet - Sunrise, 5, 76-77 [in Russian]

11.Georgievskiy, A. (1860) Obzor inostrannoy evreyskoy zhurnalistiki [Review of Foreign Jewish Journalism] Rassvet Sunrise, 10, 156-159 [in Russian]

12.Rabinovich, Y. (ed.) (1860) Peredovaya stat'ya [Editorial] Rassvet-Sunrise, 21, 338-341 [in Russian]

13.Rabinovich, Y. (ed.) (1860) Peredovaya stat'ya [Editorial] Rassvet- Sunrise, 46, 739-742 [in Russian]

14.Tsinberg, S. L. ( 1915) Istoriya evreyskoy pechati v Rossii v svyazi s obshchestvennymi techeniyami [The history of the Jewish 
press in Russia in connection with social movements] Petrograd: I. Fleytmana [in Russian]

15.Georgievskiy, A. (1860) Ocherk sovremennoy istorii yudaizma [Essay on the Contemporary History of Judaism] Russkoe slovo Russian word, 3, 1-58 [in Russian]

\section{Information about the author: \\ Olga Likhachova,}

Candidate of Historical Sciences, Associate Professor,

Associate Professor at the Department of World History and Methodology of Science, South Ukrainian National Pedagogical University named after K. D. Ushinsky 26, Staroportofrankovskaya str., Odessa, 65020, Ukraine ORCID ID: orcid.org/0000-0002-3262-4913 